\title{
Pre-Revolutionary Provinces in a Post-Napoleonic State
}

\author{
Piecing Together the United Kingdom of the Netherlands,
} $1813-1815$

\author{
BRECHT DESEURE AND DIEDERIK SMIT
}

The United Kingdom of the Netherlands was a state of contrasts. Not only did its political system combine elements from the Old Regime with the modern, postrevolutionary Napoleonic administration; it also brought together two territories with very different political backgrounds. This article explores how the new regime in the Netherlands dealt with these contrasts by focusing on the establishment of the provinces in the years 1813-1815. It argues that the appropriation of pre-modern institutions and sentiments by the authorities in post-Napoleonic Europe was an important asset for the development of the new unitary state, but that at the same time a regionally differentiated approach was indispensable to lending this policy credibility.

Het Verenigd Koninkrijk der Nederlanden was een staat vol tegenstellingen.

Niet alleen verenigde het elementen uit het Ancien Régime met een modern, Napoleontisch bestuursapparaat, ook bracht het gebiedsdelen samen met geheel verschillende politieke achtergronden. Dit artikel verkent hoe het nieuwe bewind in de Nederlanden omging met deze tegenstellingen door de aandacht te vestigen op de herinrichting van de provincies in de jaren 1814-1815. Het laat zien dat voor de nieuwe bestuurders de toe-eigening van vroegmoderne instellingen en gevoelens een belangrijk instrument was in het creëren van een nieuwe eenheidsstaat, maar ook dat een regiospecifieke aanpak noodzakelijk was om de geloofwaardigheid van dit beleid te waarborgen. 


\section{Introduction}

The construction of the nation states in Restoration Europe was a less straightforward affair than has often been assumed. Piecing together territories at the Vienna Congress was, so to speak, the easiest part. The real challenge for the new national governments was to establish a functioning state upon firm social and political foundations. As most political protagonists realised, a literal restoration of the Old Regime was both impossible and undesirable. Restoring stability in Europe would require finding the right balance between conservative and revolutionary ideas, and creating a political system based on both old and new institutions. ${ }^{1}$

In recent years, historians have increasingly paid attention to the complex and ambiguous nature of Post-Napoleonic politics. On the one hand, they have pointed out that most nation states created out of the debris of the French Empire were profoundly influenced by the revolutionary and Napoleonic experience: the Restoration monarchies incorporated to a large extent the administrative and judicial systems that had been introduced by the French Emperor in the years before. ${ }^{2}$ On the other hand, however, they have also shown that certain aspects of the Old Regime survived the Revolutionary period. On the local and regional levels in particular, old ideas, loyalties and practices were not completely forgotten. ${ }^{3}$

The United Kingdom of the Netherlands is a case in point. Created at the Vienna Congress of 1815, the conglomeration of the Northern and Southern Netherlands was in many ways a state full of contrasts: not only did the new kingdom combine elements from both old and new political systems; it also united two territories with different historical backgrounds and political cultures. The Northern Netherlands had been a confederative republic for over two hundred years and had been fully incorporated into the

C.f. Brian Vick, The Congress of Vienna. Power and politics after Napoleon (Cambridge MA 2014);

Aurelian Craiutu, A Virtue for Courageous Minds. Moderation in French Political Thought (Princeton 2012).

$2 \quad$ E.g. David Laven and Lucy Riall (eds.), Napoleon's Legacy. Problems of Government in Restoration Europe (Oxford and New York 2000); Michael Broers (ed.), The Napoleonic Empire and the New European Political Culture (Basingstoke 2012); JeanClaude Caron and Jean-Philippe Luis (eds.), Rien appris, rien oublié? Les Restaurations dans l'Europe post-napoléonienne, 1814-1830 (Rennes 2015); Michael Rowe, From Reich to State. The Rhineland in the Revolutionary Age, 1780-1830 (Cambridge 2003); Niek van Sas, De metamorfose van Nederland. Van oude orde naar moderniteit, 1750-1900 (Amsterdam 2004); Matthijs Lok, Windvanen. Napoleontische bestuurders in de Nederlandse en Franse Restauratie (1813-1820) (Amsterdam 2009).

3 E.g. Katherine B. Aaslestad, Place and Politics: Local Identity, Civic Culture, and German Nationalism in North Germany During the Revolutionary Era (Leiden and Boston 2005); Timothy Baycroft and Mark Hewitson (eds.), What is a Nation? Europe 1780-1914 (Oxford 2006); Stéphane Gerson, The Pride of Place. Local Memories and Political Culture in Nineteenth-Century France (Ithaca 2003). 
French Empire only in 1810. In contrast, the Southern Netherlands had been under continuous rule by the House of Habsburg since the fifteenth century. After a short period of semi-independence during the Brabantine Revolution, they became a part of France in 1795 and remained so for almost twenty years. The implosion of the Napoleonic Empire caused uncertainty about the region's future until the allied powers agreed - after intensive lobbying by the future King William I - to merge them with the Northern Netherlands.

The recent upsurge in publications on the history of the United Kingdom of the Netherlands has not turned a blind eye to the differences between North and South. ${ }^{4}$ Interestingly, however, one of the themes that have thus far failed to attract any scholarly attention is the position of the provinces within the new state. Although some literature on the regional heterogeneity of William I's kingdom and the constitutional history of the provinces in Belgium and the Netherlands exists, the political role of the provinces, and the influence of the provincial legacy on the constitutional basis of the United Kingdom of the Netherlands still remains largely unexplored by historians of the Low Countries. ${ }^{5}$ This is somewhat surprising, especially since both parts of the Netherlands had a strong tradition of provincialism. Both in the Dutch Republic and the Austrian Netherlands, the provinces had enjoyed a high degree of political autonomy and often pursued particularistic policies. Provincial loyalties were strong and remained an important source of identification. By the time the United Kingdom was created, the former pre-eminence of the provinces was still fresh in the minds of the state's founding fathers.

In this article, we explore the impact of the provincial legacy in both the Princedom of the Netherlands and its successor the United Kingdom of the Netherlands. By focusing on the debates of the Constitutional Commissions of 1814 and 1815 , we investigate to what extent continuities on the provincial level persisted between the Old Regime and the Kingdom of William I. How did the new regime deal with the provincial legacy? In what way were old provincial institutions, loyalties, and offices instrumental

\footnotetext{
E.g. Remieg Aerts and Gita Deneckere (eds.), Het (on)verenigd koninkrijk: Een politiek experiment in de Lage Landen (Rekkem 2015); Frank Judo and Stijn Van de Perre (eds.), Belg en Bataaf: De wording van het Verenigd Koninkrijk der Nederlanden (Antwerp 2015); Els Witte, 'Tweehonderd jaar Verenigd Koninkrijk der Nederlanden: Tussen verdeeld herdenken en vernieuwend herschrijven', Belgisch Tijdschrift voor Filologie en Geschiedenis 94 (2016) 277-316; Wilfried Uitterhoeve, Een innige vereeniging. Naar één koninkrijk van Nederland en
}

België in 1815 (Nijmegen 2015); Ido de Haan, Paul den Hoed and Henk te Velde (eds.), Een nieuwe staat. Het begin van het Koninkrijk der Nederlanden (Amsterdam 2014).

5 A notable exception is Els Witte, 'De Belgische Provinciewet in 1836 in het licht van de spanningsvelden van de transitieperiode 17901840', in: Ida Nijenhuis, Joke Roelevink and Ronald Sluijter (eds.), De leeuw met de zeven pijlen: Het gewest in het landelijk bestuur (The Hague 2010) 27-47. 
in creating a solid political and administrative foundation for the new state and how did the situation in the North in this respect differ from the one in the South?

The records of the 1814 and 1815 constitutional debates were first published in 1908-1909 in a two volume work by Herman Theodoor Colenbrander. ${ }^{6}$ Unlike some of Colenbrander's earlier works on the Patriot era and Batavian-French period which have been criticised for being inaccurate and biased, this extensive source edition is still a much-cited publication today, and considered to be an indispensable publication for scholars interested in the Dutch Restoration. In the following sections we will, therefore, use Colenbrander's source edition, as well as additional source material, to compare the discussions on the provinces in both constitutional commissions.

As a result of the different contexts and compositions of these commissions, this article is divided in two sections. The first section deals with the debates on the 1814 Constitution in the Northern Netherlands, and the position of the pre-modern provincial institutions in the new political system. The second section focuses on the discussions on the 1815 Constitution and the situation of the provinces in the Southern Netherlands. In these debates the question was no longer what role the provincial institutions would play, but rather to what extent the Northern model would fit the South. Through an analysis of both cases, we will try to gauge the challenges faced by a Restoration regime aiming at the creation of a new state out of partially reused elements.

\section{The Northern Netherlands}

Following Napoleon's defeat at the battle of Leipzig in 1813, the Northern Netherlands, which had been under French influence since the Batavian Revolution of 1795, regained their independence from the French Empire. In November of that same year a provisional government was formed at the former de facto capital of The Hague and on 2 December the son of the last Stadholder, William Frederick of Orange, was inaugurated as Sovereign Prince. Four months later, in March 1814, a new constitution was adopted, which laid the foundation of the new state and would be in force until the creation of the United Kingdom of the Netherlands in 1815.

Although the events in the winter of 1813-1814 were explicitly framed in the context of a restoration of the old political order, it was clear from the beginning that no one should take this restoration rhetoric literally. In many ways the new state resembled its direct predecessors; one could even 
argue that the regime change in fact marked the next step in a process of state-building and centralisation that had already started at the end of the eighteenth century. Like the late Batavian Republic and the Kingdom of Holland before, the new 'Princedom of the Netherlands' was supposed to be a unitary state under a single ruler. ${ }^{7}$

Still, not the entire political model of the French unitary state was adopted. Some elements proved to be more troublesome than others, most notably the introduction of the so-called departmental system. In 1798 the Northern provinces that had been sovereign states within the Republic of the United Netherlands for over two centuries were formally dissolved and replaced by executive bodies, subordinate to the new national government. These 'departments' were supposed to be no longer reminiscent of their historical predecessors; they were fewer in number, larger in size, and often bore neutral, geographical names. More importantly, the States-Provincial, which had governed the provinces since medieval times, were disbanded and succeeded by regional administrations placed under direct authority of the central government. ${ }^{8}$

This radical reform, however, worked in theory, rather than practice. Already in 1801 the implementation of the departmental system was partially reversed, and in the years following the different regimes continued to struggle with the question of the departments. New names and new borders followed in rapid succession: Amsterdam, for example, was successively situated in 'Departement van den Amstel' (1798-1801), 'Departement Holland' (1801-1806), 'Departement Amstelland'(1806-1810), and 'Département du Zuiderzée' (1810-1813). ${ }^{9}$ After the independence from the French Empire, the internal territorial divisions were again revised; this time, however, the revision was more lasting and even had some semblance of a proper restoration: although the Netherlands remained a unitary state, built on a modern Napoleonic administration, the original provincial names, borders, and even some specific regional offices and privileges were reintroduced. Moreover, the restored provinces were given an important position in the organisation of the new suffrage system: from 1814 onwards it would again be the members of the States-Provincial who elected the members of the national parliament, the States-General. ${ }^{10}$

Why did the Dutch government of 1814 restore the States-Provincial and similar Old Regime institutions? To understand this action one has to

C.f. Martijn van der Burg, Nederland onder Franse invloed. Cultuurtransfer en staatsvorming in de napoleontische tijd, 1799-1813 (Amsterdam 2009); Annie Jourdan, 'Staats- en natievorming in de tijd van Lodewijk Napoleon, Nederland als “objet de désir"', De Negentiende Eeuw 30:3/4 (2006) 132146.
8 Herman Sietsma, 'Korte schets van de geschiedenis van de provincies', in: Idem and Arno Seinstra (eds.), Provincies van binnen en van buiten (Nieuwegein 2012) 30-33.

9 Sietsma, 'Korte schets', 30-32.

10 Ibidem, 34-35. 
study the records of its Constitutional Commission. Chaired by Gijsbert Karel van Hogendorp, this commission was formed in the direct aftermath of the inauguration of the Prince of Orange. It consisted of thirteen members, who represented both the old and the new regimes. On one side stood the so-called windvanen (turncoats), men like Willem Röell, Cornelis Elout and Cornelis van Maanen, who had been the founding fathers of the unitary state and owed much of their careers to the new Napoleonic administration. Not surprisingly, they largely sympathised with the French legacy; for them there was no need to overturn or adjust the departmental system. ${ }^{11}$ On the other side were the men who had been side-lined during the Batavian-French period: the typical Ancien Régime dignitaries who had been forced to resign from office in 1795 and who in many cases had followed the House of Orange into exile. These men, including Idzerd Aebinga van Humalda, Ocker Repelaer van Driel and Willem van Lynden van Blitterswijk, had not been on the political stage for almost twenty years and were therefore more sceptical of the new situation. It was Van Hogendorp's task to unite both parties and to come up with a compromise that would satisfy both the old and new elites. ${ }^{12}$

During the deliberations of the 1814 Constitutional Commission neither side proposed to restore the sovereign political powers of the provinces; there was little question that the unitary state would be preserved. Nor was there any discussion on the division of the realm: both the borders and the names of the old provinces of the Old Regime would be restored. Rather, the most important subject of debate was the question whether the provinces would regain their former institutions and how these institutions would function within the new state. ${ }^{13}$ For example, should the former regional assemblies, the States-Provincial, be part of the new representative system, and what role should they play there?

To Van Maanen, Röell and Elout the answer to questions like these was clear. They believed that any representative body at the regional level was redundant now that the provinces were no longer sovereign powers. According to them, it would be deceptive or even dangerous to restore the States-Provincial. Not only would this create the impression that the provinces were as powerful as they had been before; it could also revive 'the old spirit of provincialism' that had caused so much trouble in the past. Instead of referring to the old 'States', Van Maanen and his supporters therefore suggested the creation of a 'provincial administration' - a term that was less politically and historically charged. ${ }^{14}$ Colenbrander I) 157.

Diederick Slijkerman, Wonderjaren: Gijsbert Karel van Hogendorp, wegbereider van Nederland (Amsterdam 2013).
13 Colenbrander I, 157-199, 'Vergaderingen van 6-12 januari 1814'.

14 Colenbrander I, 167, 'Vergadering van donderdag 6 januari 1814'. All translations of citations are by the authors of this article. 
In the eyes of Gijsbert Karel van Hogendorp, however, this was not an option. He believed that many of the old provincial institutions could be very useful, even in the context of the new unitary state. In his 'Comments on the Constitution' he argued that in the Republic 'the government of the provinces, cities and villages had functioned quite well' and, therefore, required only a few 'slight modifications', before it could again serve as a constitutional 'basis' for the state. As long as the provincial and local governments did not interfere in national politics too much, he continued, 'the preservation of all that is provincial is useful, and will be highly appreciated by the nation as a whole'. ${ }^{15}$

In one of the first meetings of the Constitutional Commission, Van Hogendorp elaborated his argument. He pointed out that provincial representation was important for at least two reasons. First of all, because the provincial level could serve as a political platform for the nobility in the Northern Netherlands, especially in the provinces outside of Holland. Unlike merchants, lawyers and other well-to-do burghers, the nobility had played only a minor role in Dutch politics. Traditionally, noblemen had rarely been represented in the local city councils or in the professional bureaucratic elite. If the national government wished to include a class of 'nobles' in the political system and create support for the new Prince, the most obvious way, therefore, was through provincial representation. Secondly, Van Hogendorp argued, provincial representation tied in with the 'spirit' of the country and its inhabitants. After all, the people of the Netherlands were not only Dutchmen, they were also 'Hollander, Frisian and Gueldersman'; denying this 'spirit of the provinces' was an act against nature itself. ${ }^{16}$

Most of the other Old Regime dignitaries in the Commission agreed with Van Hogendorp. His remarks regarding the position of nobility, in particular, were met with approval. The Guelders Count Van Lynden, for example, elaborated on Van Hogendorp's argument by pointing out that the nobility was essentially provincial. ${ }^{17}$ According to him, the future kingdom needed both the old provinces and the so-called Ridderschap, the body of the States-Provincial that had represented the nobility before the Batavian Revolution of 1795 , as without them many noblemen would be excluded from politics, especially in the more rural parts of the country. Van Lynden also contested the notion of, amongst others, Röell and Van Maanen that the reintroduction of the States-Provincial and the Ridderschap would be misleading. On the contrary, it was exactly their counter-proposal - to create a 'national nobility' and reduce the provinces to sheer administrative units - that would deceive the people. ${ }^{18}$ op de Grondwet', in: Colenbrander I, 57; Nico Randeraad, 'Politiek en bestuur', in: Roel Pots and Nico Randeraad (eds.), Behoedzaam bestuur. Twee eeuwen provincie Zuid-Holland (Leiden 2014) 45.
Colenbrander I, 163 and 169, 'Vergadering van donderdag 6 januari 1814'.

17 Colenbrander I, 203, 'Vergadering van woensdag 12 januari 1814 '.

18 Colenbrander I, 195, 'Vergadering van woensdag 11 januari 1814 '. 
Eventually, a majority voted in support of traditional provincial representation. As a result, the Commission not only proposed a restoration of the States-Provincial and their specific representative bodies, its members also agreed that these assemblies would be given the freedom to draw up their own rules and regulations: they would decide how their future meetings would be organised and which of their region-specific offices and privileges would return. However, there were a few strings attached. To respond to the wishes of centralists like Röell and Van Maanen, but also to avoid a possible return of provincial particularism, the Commission made sure the new sovereign would keep the upper hand. First of all, the Prince would be the one who would convoke the States-Provincial for their first meeting, and hence decide who was in and who was out. Secondly, each province would be given a royal Governor, who would act on the Prince's behalf and preside over the States' meetings. ${ }^{19}$ And finally, all the Provincial Rules (Provinciale Reglementen) drawn up by the States had to be proclaimed by Royal Decree (Koninklijk Besluit), thus giving the Prince the last word. ${ }^{20}$

In this way, the return of the old States-Provincial functioned as a double-edged sword, serving both the political powers in the centre and in the region. On the one hand, the States provided a firm and solid foundation for the new regime. By restoring traditional institutions like the Ridderschappen the Prince of Orange responded to the hopes of the old elites, while at the same time it gave him an opportunity to reward the bureaucrats for their newly sworn loyalty: following his installation as sovereign, he ennobled not only many Old Regime dignitaries, but also a significant part of the former Napoleonic establishment. ${ }^{21}$ Furthermore, by giving the States-Provincial a key position in the new suffrage system, the Prince had an indirect influence on the composition of the new national parliament. ${ }^{22}$

On the other hand, the system worked to the advantage of the representatives themselves: by reviving the States-Provincial and leaving them to a large extent in charge of their own future, it enabled them to secure their regional interests, both politically and economicly. ${ }^{23}$ This applied first of all to the old Orangist families who had been side-lined during the Batavian-French period. Whether one looks at the composition of the

pacificerende rol van commissarissen des Konings
en burgemeesters', in: Hans Blom and Jaap Talsma
(eds.), De verzuiling voorbij: Godsdienst, stand en
natie in de lange negentiende eeuw (Amsterdam
2000) 134-153.
Paul Janssens, 'De restauratie van de adelstand
in het Koninkrijk der Nederlanden', Belgisch
Tijdschrift voor Nieuwste Geschiedenis 12:3 (1981)
395.

21 Janssens, 'De restauratie van de adelstand in het Koninkrijk der Nederlanden', 329-342.

22 Ineke Secker, 'Onder koninklijke voogdij. De Tweede Kamer vindt haar plaats binnen de constitutionele monarchie', in: Remieg Aerts et al. (eds.), In dit huis. Twee eeuwen Tweede Kamer (Amsterdam 2015) 279.

23 Janssens, 'De restauratie van de adelstand', 329342. 
States-Provincial, the Ridderschappen or the provincial representatives in the States-General, it is immediately apparent that many of the names of the officials are the same as in the Old Regime. Families like the Van Lyndens in Guelderland, Bentinck in Overijssel, Van Aylva in Frisia and Van Tuyll van Serooskerken in Utrecht, which had been the backbone of the so-called Stadholderian System in the second half of the eighteenth century, would again dominate the meetings of the various representative bodies. ${ }^{24}$ Even in the case of the newly appointed provincial governors, most men came from the traditional ruling families of the Republic: out of the ten administrators eight hailed from staunch Orangist families and seven of them were members of the old nobility. Only the governor of the new province of Brabant, Carel Hultman, and the governor of new Southern district of Holland, Frédéric van Leyden, could be considered homines novi. ${ }^{25}$

Moreover, once in power the representatives used the restored provincial institutions to reclaim some of the rights and privileges that had been lost after the Batavian Revolution. In this context, the Provincial Rules in particular proved key in anchoring the provincial establishment in the new state. In nearly all provinces the legal and political structures of the old Regime served as a blueprint for the Reglementen: a principle that operated to the advantage of the political elite in the provinces. In Frisia, for example, the States-Provincial decided to continue in the same old way as much as possible. As a result, many of the traditional ruling families regained control over their local communities. Not only were they again entitled to administer justice; they also reclaimed the right to appoint rural administrators or grietmannen: a privilege that dated from the Middle Ages and had been one of pillars of the renowned 'Frisian Freedom' in early modern times. ${ }^{26}$

Similarly, in nearby Groningen the oligarchical families exploited the old provincial rights and privileges to strengthen their positions. In 1816, for example, the States-Provincial reintroduced the right of collation. This privilege, which had been assumed by the representatives of Stad en Lande after the Reformation, enabled local noblemen or dignitaries to appoint clergymen in their own parishes; they held the right to put forward a nominee, who subsequently would be installed by the provincial government. The decision de politiek-bestuurlijke elite van de Republiek in de eerste helft van de negentiende eeuw', in: Ida Nijenhuis, Joke Roelevink and Ronald Sluijter (eds.), De leeuw met de zeven pijlen, 147-164; Jos Gabriëls, De heren als dienaren en de dienaar als heer. Het stadhouderlijk stelsel in de tweede helft van de achttiende eeuw (The Hague 1990). het politieke krachtenveld van Noord-Brabant, 18131830 (Tilburg 1988) 36-38; Randeraad, 'Politiek en bestuur', 46-47. Anton Falck, Reglement omtrent de zamenstelling van de Staten der provincie Vriesland (The Hague 1814); Idem, Reglement omtrent de zamenstelling der staten, op het bestuur ten platten lande en voor het bestuur der steden in de provincie Vriesland (Leeuwarden 1826). 
to continue this practice reinforced the ties between the noble families and the church and provided Groningen's old elites with a powerful instrument in both political and religious matters. ${ }^{27}$

Also in other provinces, the drafting of the Provincial Rules went hand in hand with the revival of semi-feudal practices and offices. In Overijssel, for example, the States-Provincial tightened their grip on the countryside by reinstating the former office of reeve (drost), while in neighbouring Guelderland they granted the Ridderschap several ceremonial prerogatives, thus restoring the traditional hierarchy among their members. ${ }^{28}$ Moreover, almost everywhere in the Northern Netherlands the reconstruction of provincial administrations was coupled with a restoration of former seigneuries (heerlijkheden). These private dominions, which had lost their special legal status during the Batavian-French period, would once again enjoy a wide spectrum of privileges, ranging from hunting and fishing rights to the right to nominate local officials. ${ }^{29}$ However, as in the case of all restored institutions, the exact nature and limitations of these seigneurial rights were strictly defined by the Provincial Rules. In Holland, for instance, the Rules prescribed that, as in the past, local lords could personally appoint their sheriffs and other rural administrators, but also that every appointed candidate needed the approval of the new sovereign. ${ }^{30}$

Now what do these examples tell us about the persistence of provincial institutions in the early nineteenth century? Nowadays names like Frisia, Groningen, Guelderland and Holland are primarily associated with regional languages, costumes and other distinctive features. These folkloristic and more 'popular' expressions of provincialism, however, would get the upper hand only in the second half of the century. ${ }^{31}$ In the first two decades of the nineteenth century, the provinces served primarily as a political platform and a crucial link between the old and new political orders. Groningen, geapprobeerd bij Koninglijk Besluit van den 3 julij 1816 (Groningen 1816); Jonn van Zuthem, 'Een nieuwe provincie 1814-1848', in: Maarten Duijvendak et al. (eds.), Geschiedenis van Groningen, deel III Nieuwste tijd - Heden (Zwolle 2009) 55-121. Idem, Reglement van bestuur ten plattenlande van de provincie Overijssel (Zwolle 1818) 20-29; Idem, Reglement voor het platteland van de Gemeente Gelderland, Aldus goedgekeurd en geapprobeerd door 's Konings Besluit, van den 22 juny 1817 (Arnhem 1817); Olav Moorman van Kappen, 'Het provinciaal bestuur van Gelderland in de negentiende eeuw: inrichting en werkzaamheid', in: Kuppers, Van Gelre tot Gelderland, 55-57. der Burg, Heerlijkheden in Nederland (Hilversum 2008) 21. der provincie Holland, zoo als hetzelve op voordragt der Staten, bij 's konings besluiten van 13 december 1815, in de gemeenten verdeeld is (Amsterdam 1816). Musealisering en nationalisering van de volkscultuur van Nederland, 1815-1940 (Nijmegen 2001); Dolly Verhoeven (ed.), Klederdracht en kleedgedrag: Het kostuum Harer Majesteits onderdanen 1898-1998 (Nijmegen 1998); Goffe Jensma, Het tasje van Salverda. Burgerlijk bewustzijn en Friese identiteit in de negentiende eeuw (Leeuwarden 1998). 


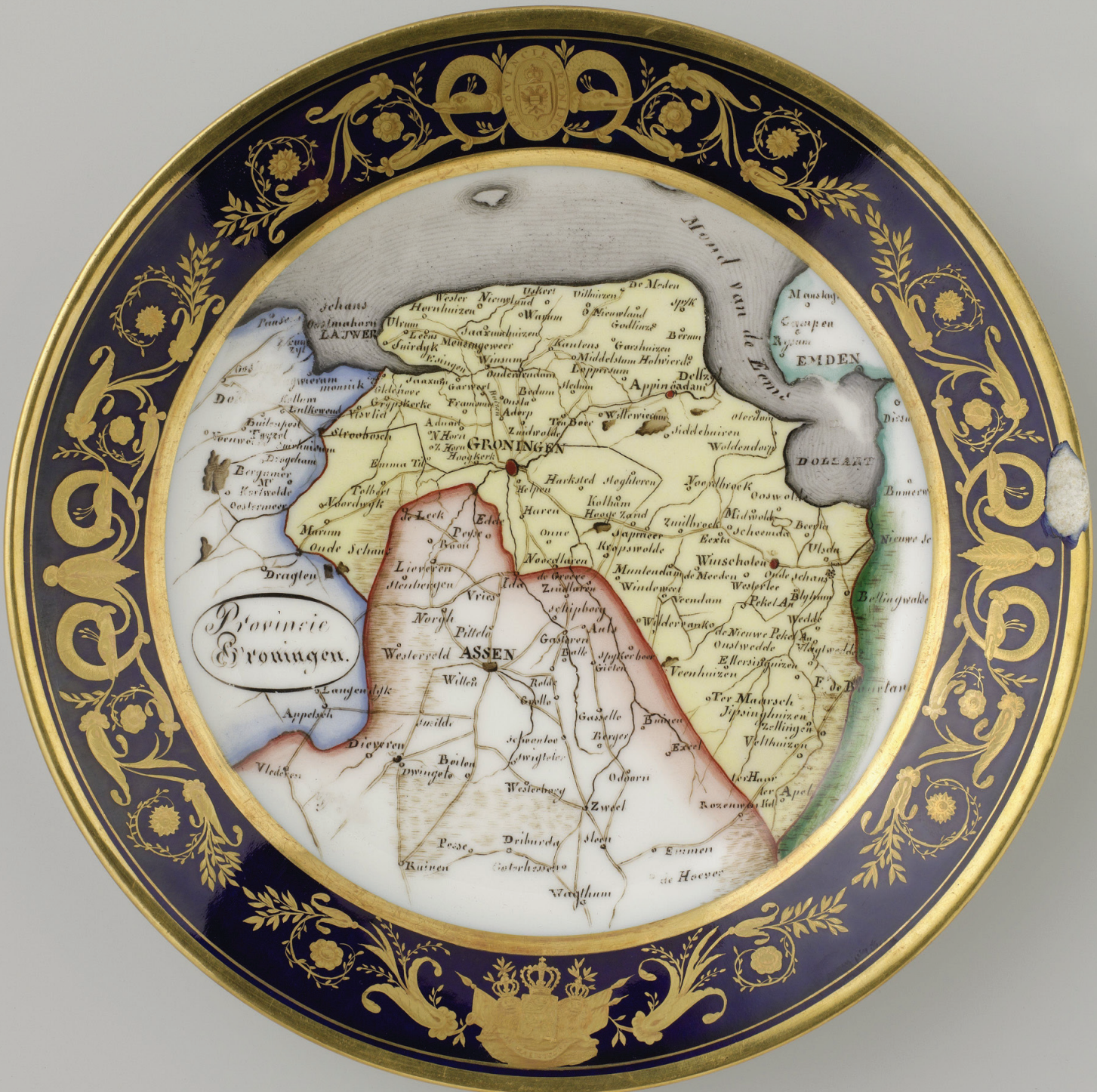

$\Delta$

Plate decorated with an image of the province of Groningen, anonymous, 1822, Collection Rijksmuseum, Amsterdam. http://hdl.handle.net/10934/RMooo1. COLLECT. 490758 . 
With its specific offices, privileges and rights the traditional provincial framework appealed first and foremost to those dignitaries who had lost power during the Batavian-French period: they used the old institutions to regain political control and reinforce their socio-economic status. To them the rehabilitation of the old provinces quite literally fulfilled the promises Van Hogendorp had made in his famous 1813 proclamation: not only did the restoration at the provincial level 'revive the old times', it also allowed 'the nobles to return to power' ('De oude tijden komen weerom [...] alle de aanzienlijken komen in de regeering'). ${ }^{32}$

Paradoxically, however, the successful restoration of the old provincial hierarchy and the return of region-specific rights and institutions can be explained only in the context of the new unitary state. Although the StatesProvincial were basically given free rein over the institutional structure of the provincial administration, in the end it was the central government which had the final say on the appointment of officials and the policies to be conducted. More than anything, it was the Commission's wish to unite the old and new Dutch elites around the sovereign that enabled the restoration of the prerevolutionary provinces in the North. Its main objective was to create a solid foundation for the new central government to build on: a leading class of nobles, which was institutionally rooted in society but also bound to the new central government. The old provinces and their institutions, in particular, proved to be instrumental in achieving exactly that goal.

\section{The Southern Netherlands}

At first glance, the position of the provinces in the Southern Netherlands largely resembled the situation in the North. Like their northern counterparts, the provinces in the South, too, would function as important building blocks for the new state, linking historical names and traditional leading families to the central government. However, the way in which the Southern provinces were restored differed in some respects from the way this had happened in the northern parts of the Kingdom. Not only did the Constitutional Commission not restore the original territories of the former Austrian Netherlands, but also the States-Provincial in the Southern Netherlands would be different from their historical predecessors. Moreover, in the South, not all historical references were greeted with great enthusiasm.

Following the incorporation of nine former French departments in the Southern Low Countries, the Kingdom almost doubled in size and almost

Instituut, The Hague) [accessed on 1 December 2017]. 
tripled in population. The integration of the new territories necessitated a constitutional revision, overseen by a new Constitutional Commission. The Commission counted twenty-two members, equally divided between North and South. ${ }^{33}$ It was again chaired by Van Hogendorp. The new commission's task differed from the old one. Rather than drawing up a new constitution, it needed to adapt the existing constitution to the Southern territories. Concerning the provinces, the accent was now much more on questions of geography and terminology than on the institutional arrangement (which was not likely to be revised) or the regional role of the Southern nobility. As we will see, the latter group was rather more concerned with restoring its political role on the national level.

In its report of 13 July 1815 to King William, the Commission reported the following on the provincial organisation:
When dividing the realm into provinces, we have, for the Northern provinces, followed the division laid down in the first Constitution. We have returned the provinces to their old borders, save small adjustments in their common interest. The same interest has made us adopt, for the Southern provinces, a different principle. We have limited ourselves to changing the names of the departments. An interval of twenty years' time has created bonds and relations between the inhabitants of these departments. Severing those relations would harm countless interests and occasion numerous difficulties for the government, which are useless and harmful for the inhabitants. ${ }^{34}$

Indeed, the Southern Provinces were designed around a markedly different principle than the Northern ones. Instead of re-establishing the ancient duchies and counties and restoring their historic territories, as had been done in the North, the existing French departments were retained. Only their names changed, as the names of the historical provinces were reintroduced. The result was a peculiar amalgam of Old Regime decorum and efficient postrevolutionary French state organisation.

The departmental system was a product of the anti-historical French Revolution. It had been conceived with the explicit aim of breaking up the historical provinces of the Old Regime and even wiping out their memory. By the late eighteenth century, the Austrian Netherlands consisted of eleven sovereign provinces, the largest of which were the Duchies of Brabant and

der Nederlanden van 1815 (Bruges and The Hague 2016) 19 .

34

Colenbrander, Ontstaan der grondwet, II (hereafter: Colenbrander II), 550, 'Rapport présenté au Roi par la Commission chargée de la révision de la loi fondamentale des Pays-Bas-Unis'. 
Luxembourg and the Counties of Flanders, Hainaut and Namur. Upon their annexation to France in 1795, these provinces, together with the Princebishopric of Liège and a few other adjacent territories that had not historically belonged to the Austrian Netherlands, were replaced by nine departments. 35 The County of Flanders, for example, was divided into the Lys and Escaut departments. The Duchy of Luxembourg and the Counties of Bouillon and Vianden were merged into the Forêts department. The department of Jemappes (named in commemoration of the French victory over the Austrians at Jemappes in 1794) was created out of the old County of Hainaut and the Tournaisis province, plus parts of the County of Namur and the Prince-bishopric of Liège.

The departmental system had been introduced in the Northern Netherlands, too, albeit later than in the South and, in the end, in a less radical way. In the South, the departmental system was more deeply ingrained; at the time of the reunion with the United Kingdom of the Netherlands it had been functioning for twenty years. For that reason, the Belgian members of the Constitutional Commission of 1815 pleaded in favour of retaining the departments. The Count d'Arschot phrased it as follows:

\section{We have been departments for over twenty years. As a consequence, people and things have established mutual relations; so I would prefer to retain the departments for us, with a few necessary changes, but taking back the old names. ${ }^{36}$}

The Commission moreover reported that the departments had precisely the right size ('neither too small, nor too large') to fit the general organisation of the Kingdom. ${ }^{37}$ The entire administrative apparatus had the departments as a basis. Changing all of that would be a Herculean task without any real benefit, the members agreed. Only the names of the Southern provinces needed 'to be derived from different sources than those after which the nine united departments have been named at the end of September 1795 by the French government'. One member disagreed: Jan-Jozef Raepsaet, the most hardboiled reactionary in the commission. Raepsaet claimed not to understand why the restoration of the ancient provinces should be more burdensome than their abolition by the French. He warned that to preserve the institutions introduced under French rule was to jeopardise Belgium's position as a buffer against French expansionism, as it had been intended by the allied powers. The Belgians would never feel free in the United Kingdom of the Netherlands without the enjoyment of their old habits and traditions, he claimed. ${ }^{38}$ provincies, één land. 150 jaar provinciewet 1836-1986. West-Vlaanderen (Brussels 1986). 10 Mei $1815^{\prime}$
Observations d'un belge sur le sort éventuel des 
Raepsaet was not supported on this point or on many others. By contrast, the restoration of the old provincial names was considered selfevident by the Commission members. The link between the names and the historical territories was loosened, however. Thus, the Lys and Escaut departments were renamed West and East Flanders respectively. ${ }^{39}$ The departments Bouches-du-Rhin and Dyle became the respective provinces of North and South Brabant. The Deux-Nèthes department, most of which had historically belonged to the Duchy of Brabant, became the province of Antwerp (named after the old margraviate). The Ourthe department became the province of Liège, although in reality it comprised portions of no fewer than six former principalities (Liège, Limburg, Luxembourg, Brabant, Bouillon and Stavelot-Malmédy), while another part of the former Prince-bishopric went on to join the province of Maastricht. The Sambre-etMeuse department was now known as the province of Namur, although this province, too, contained parts of the former principalities Liège, Luxembourg and Brabant. In short, preservation of the old names and territorial rationalisation prevailed over historical accuracy.

King William himself had an important share in the restoration of the old names. On his initiative, the name of the province of Maastricht (created out of the departments of Meuse-Inférieur and Roër) became Limburg. ${ }^{40} \mathrm{It}$ did not matter much that the historical territory of the Duchy of Limburg was now largely situated in the province of Liège, while the province of Limburg was an amalgam of territories that, save for a handful of villages, had not even belonged to the historical duchy. The king insisted on preserving the name of the old and prestigious duchy ('Duke of Limburg' figuring among his dynastic titles). ${ }^{41} \mathrm{He}$ similarly regretted that the name of the ancient province of Tournaisis (around the city of Tournai) was lost due to its incorporation into the province of Hainaut. ${ }^{42}$

The king moreover decided to restore the official order of precedence for the provinces stipulated by ordinance of the Emperor Charles v, when all of the Netherlands had been united. ${ }^{43}$ The Constitution of 1814 had already restored the old order of precedence of the provinces in the Dutch Republic: being a former duchy, Guelderland, for example, ranked in hierarchy above

Dhondt, 'Inaugurating a Dutch Napoleon? Conservative Criticism of the 1815 Constitution of the United Kingdom of the Netherlands', in: Ulrike Müssig (ed.), Reconsidering Constitutional Formation II: Decisive Constitutional Normativity (Berlin 2017); Evert Peeters, Het labyrint van het verleden. Natie, vrijheid en geweld in de Belgische geschiedschrijving (1787-1850) (Leuven 2003) 64 . An independent province of West Flanders had been created in the eighteenth century following

the Peace of Utrecht, but it was much smaller than the newly created one.

40

41

43 juli $1815^{\prime}$. juli $1815^{\prime}$
Colenbrander, II, 522, 'Vergadering van zaterdag 8

Joep Leerssen, 'De Nederlandse natie', in: Ido de Haan et al. (eds.), Een nieuwe staat (2013) 323.

Colenbrander II, 503 Colenbrander II, 522, 'Vergadering van zaterdag 8 
counties like Holland and Zeeland and lordships like Utrecht and Frisia. The integration of the Southern Netherlands required a return to an earlier period in time, as well as some creative adaptation of the Old Regime past to present circumstances. After all, the Prince-bishopric of Liège had never been part of the Seventeen Provinces. The province of Liège was inserted between Guelderland and Flanders, i.e. after the duchies and before the counties. The old order of precedence had the additional advantage of mixing Northern and Southern provinces, enhancing the impression of 'un amalgame intime et complète'. ${ }^{44}$

The Constitutional Commission, for its part, had not been able to reach unanimity on the question of precedence. The Count d'Arschot had derisively rejected Van Lynden's proposal of restoring the historical order: 'These are old ideas, and worth nothing.' Queysen added that the proposal subverted the principle of the unitary state: the king derived his power from the constitution only, not from any ancient claims to princely titles or suzerainty. He did not see the use of bringing up these old ideas, which he called childish. Van Lynden dismissed these objections, however, by pointing out their functionality: ' $\mathrm{Y}] \mathrm{es}$, but those children cling to them, and they do merit some consideration still. ${ }^{45}$ His answer perfectly illustrates the ambiguity of the Restoration regimes vis-à-vis the past, as they strove to preserve the useful innovations of the revolutionary and Napoleonic regimes while suggesting continuity with the pre-revolutionary past. ${ }^{46}$ Harking back to the Seventeen Provinces fitted the restoration policies of Van Hogendorp and King William, both of whom promoted the Burgundian Netherlands as the ideal historical precedent to legitimise the new state. 47

But William's history politics, aimed at the creation of a national past common to all of the new country, suffered from a lack of consistency. ${ }^{48}$

Colenbrander II, 193, 'Vergadering van maandag 22 mei $1815^{\prime}$.

Colenbrander, II, 202, 'Vergadering van maandag 22 mei $1815^{\prime}$

Frank Judo, 'De kracht van het negatieve voorbeeld', in: André Alen et al. (eds.),

De Grondwet van het Verenigd Koninkrijk der Nederlanden, 177; Niek van Sas, 'Het Grote Nederland van Willem I: Een schone slaapster die niet wakker wilde worden', in: Coen Tamse and Els Witte (eds.), Staats- en natievorming in Willem I's koninkrijk (1815-1830) (Brussels 1991) 179. Stefaan Marteel, 'Polemieken over natievorming in het Verenigd Koninkrijk der Nederlanden. Een blik op de intellectuele wortels van het
Belgisch nationalisme', in: Rik Vosters and Janneke Weijermars (eds.), Taal, natievorming en cultuurbeleid onder Willem I (Brussels 2012) 38; Niek van Sas, 'Onder waarborging eener wijze constitutie. Grondwet en politiek, 1813-1848', in: Van Sas, De metamorfose van Nederland, 462; I.J.H. Worst, 'Koning Willem I. Het begin van “ons grondwettig volksbestaan"', in: Tamse and Witte (eds.), Staats- en natievorming in Willem i's koninkrijk, 58.

48 Remieg Aerts, 'Een andere geschiedenis. Een beschouwing over de scheiding van 1830', in: Piet Rietbergen and Tom Verschaffel (eds.), De erfenis van 1830 (Leuven 2006) 26; Ido de Haan, 'Een nieuwe staat', in: Haan, Een nieuwe staat, 25; 
The complications of the historical scheme surfaced in the Constitutional Commission of 1815 . In its final report, the Commission wrote that the constitution 'has not reconstructed that which was completely worn out by time, but it has restored everything which could usefully be preserved. In that spirit, it has reestablished the States-Provincial, but modified their organisation'. ${ }^{49}$ Presenting the constitution as an updated version of the rights and traditions enshrined in the ancient constitutions indeed became a standard legitimizing practice under the United Kingdom of the Netherlands..$^{50}$ But concrete historical references quickly ignited controversies. Southern members, for instance, took offence at the mention of the Union of Utrecht (1579) in article 121 of the Constitution of 1814, concerning the obligation to bear arms. The members argued that the Union of Utrecht was alien to them and that they had no connection to it. Van Hogendorp therefore proposed to cite the Pacification of Ghent (1576) instead, as this charter had extended to most of the Northern and Southern Netherlands. ${ }^{51}$

The inauguration of the king was another powerful means to suggest continuity with the Old Regime past. The members agreed that the king was to take the oath in an open-air session of the States-General, in a manner resembling as much as possible the historical inaugurations in the Southern tradition..$^{52}$ According to article 31 of the 1814 Constitution, the inauguration required the members of the States-General, as well as the States-Provincial, to swear an oath to the king in turn. The prescription yet again brought the Old Regime provincial traditions to mind, when the prince had been inaugurated, in each province separately, before the assembled States-Provincial. Several members of the 1815 Constitutional Commission proposed to abolish the article, because of its subversive potential. ${ }^{53}$ The nation was fully represented by the States-General, they argued, so the oath of the States-Provincial was

Tamse en Witte, 'Woord vooraf', in: Tamse and Witte (eds.), Staats- en natievorming in Willem I's koninkrijk, 10; Van Sas, 'Het Grote Nederland', 180. par la Commission chargée de la révision de la loi fondamentale des Pays-Bas-Unis'.

Remieg Aerts, 'Het ingesleten pad. Over de betekenis van de grondwet van 1815', in: André Alen et al. (eds.), De Grondwet van het Verenigd Koninkrijk der Nederlanden van 1815 (Bruges and The Hague 2016) 49; Brecht Deseure, 'From Pragmatic Conservatism to Formal Continuity. Nineteenth-century Views on the Old Regime Origins of the Belgian Constitution', Giornale di Storia Costituzionale/Journal for Constitutional
History 32:2 (2016) 257-277; Stefaan Marteel, 'Van "oude constitutie" tot liberale grondwet. Het Belgische politieke natiebesef tussen 1815 en 1830', in: Rietbergen and Verschaffel (eds.), De erfenis van 1830, 35-52; Bart van Poelgeest, 'Tussen oud en nieuw: Het ontwerpen van de grondwet als een rechtshistorisch mozaïek', in: De Haan, Een nieuwe staat, 67-75. Colenbrander II, 296, 'Vergadering van vrijdag 2 juni 1815 '. Colenbrander II, 108, 'Vergadering van maandag 8 mei 1815 '.

Colenbrander II, 419-420, 'Vergadering van zaterdag 17 juni 1815 '. 
redundant. Worse, the provincial oath might, over time, lead the StatesProvincial into believing that they had a part in the sovereign power and that the inauguration was not valid without their consent. Such false ideas might awaken the spirit of federalism, which was anathema to the proponents of the unitary state. ${ }^{54}$ The majority nevertheless voted to retain the provincial oath, arguing that it was phrased in the manner of an oath of obedience and not of an oath of fealty. Taking an oath of obedience to the king was an obligation for all subjects holding office in the realm anyway, the members of the StatesProvincial included. ${ }^{55}$

The preceding examples show that symbolic continuity with the prerevolutionary provinces was pursued in the South as well as in the North, even if the historical territories were not restored. The re-establishment of the old forms was part of a systematic attempt to gain legitimacy for the new regime. The provinces were also meant as power bases for the pre-revolutionary elites. This was certainly true for the South as well as for the North. To be sure, the reintroduction of seigniorial rights was not pursued in the South, as it was hardly incompatible with the modern departmental administration. But many pre-revolutionary noble families regained political prominence by their inclusion in the Ridderschappen.

In this case, however, the suggestion of historical continuity with the Old Regime's past did not work so well in the South. The function of the old States-Provincial had been quite different in the North and the South, as the Count de Merode explained: 'We Belgians never had representatives, whereas the Dutch did, in their States: these were the representatives of the Nation, whereas our States were not; they were merely an intermediary body between the People and the Prince, but the Prince had the imperium.${ }^{56}$ The nobility had been only partially represented in the States-Provincial of most of the Southern principalities, or had not even been represented at all, as in Flanders. Moreover, the Catholic clergy, who had traditionally made up the first estate, were excluded from the States-Provincial. As in the Northern Netherlands, the States would represent nobility, cities and countryside.

Continuity with the Old Regime past was more blatant on the level of local government, where the aristocracy regained the prominence it had held before. ${ }^{57}$ But to really restore the nobility to power required, for the Southern Commission members, the introduction of bicameralism. ${ }^{58}$ The nobility

The issue had also caused controversy in the first Constitutional Commission, see Colenbrander I, 93, 'Vergadering van woensdag 29 december 1813'. See: Van Poelgeest, 'Tussen oud en nieuw', 68. Colenbrander II, 419-420, 'Vergadering van zaterdag 17 juni $1815^{\prime}$

Colenbrander II, 307, 'Vergadering van maandag 5 juni $1815^{\prime}$.
57 Janssens, 'De restauratie van de adelstand', 409; Els Witte, 'Wijzigingen in de Belgische elite in 1830', Bijdragen en Mededelingen betreffende de Geschiedenis der Nederlanden 94:2 (1979) 226-252.

58 Colenbrander II, 'Vergadering van woensdag 10 mei 1815'; 'Vergadering van maandag 22 mei 1815'; 'Vergadering van maandag 5 juni 1815'. 

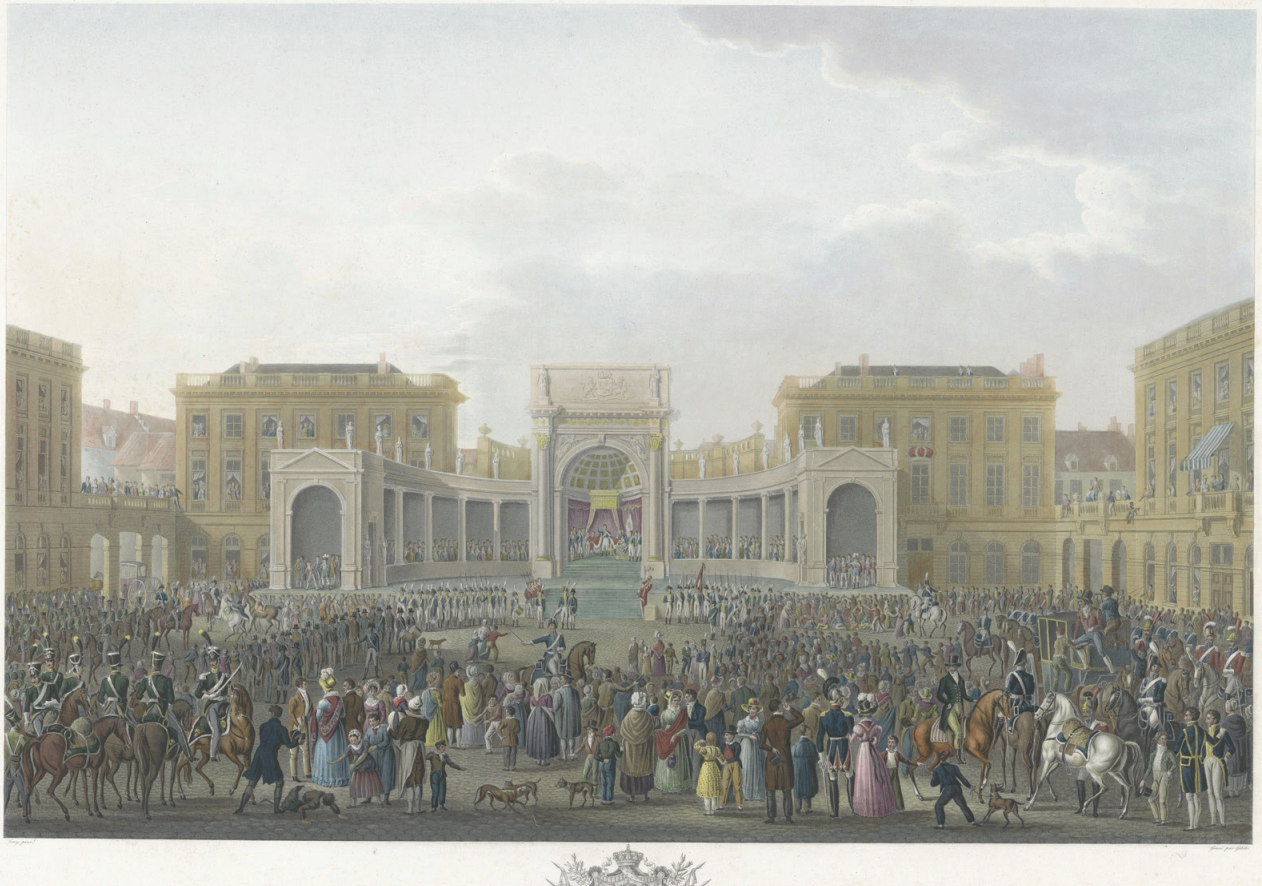

$\boldsymbol{\Delta}$

Royal inauguration of William I in Brussels, 21 September 1815, Johann Nepomuk Gibèle, 1825-1826, Collection Rijksmuseum, Amsterdam. http://hdl. handle.net/10934/RMooo1.COLLECT.554527. 
was needed, they agreed, as an indispensable mainstay of the monarchy, to guarantee the conservative element and to counterbalance the elected Second Chamber. ${ }^{59}$ To adapt the constitution to the Belgian character and traditions, the nobility's 'political existence and moral force' needed to be revived. ${ }^{60}$ On this point, the Southern monarchical tradition clashed with the Dutch republican heritage. The introduction of a noble chamber was unacceptable for the Northern members, as it had been in $1814 \cdot{ }^{61} \mathrm{~A}$ compromise was reached in the form of a First Chamber whose membership was not restricted to the nobility. Instead, members of the First Chamber were appointed for life by the king among 'those who, by their service to the State, their birth or their wealth, belong to the most distinguished people in the realm'. ${ }^{62}$ The result was practically the same, as the nobility quasi monopolised the First Chamber. ${ }^{63}$ The controversy goes to show that 'historical' solutions to contemporary political challenges that worked for one part of the country did not necessarily do so for the other, as a result of their different historical and political traditions.

The question remains what effect this half-hearted restoration of the ancient provinces had on their inhabitants. Did they consider the reuse of the old names 'childish', or did it actually reinforce provincial (and through it, national) identification? In the South, as in the North, regional identities were strong. Until the end of the Old Regime the Austrian Netherlands had been a collection of sovereign provinces with their own charters, privileges and institutions. This provincial autonomy created a sense of identity, despite the development of a sense of mutual belonging or 'Belgianness' in the second half of the eighteenth century. ${ }^{64}$ Provincial particularism continued to prevail 408; Witte, 'De Grondwet van het Verenigd Koninkrijk'.

60 402. The proposal of a majority of the Southern members in the 1815 Commission had been less exclusive, by providing for the automatic ennoblement of non-noble members. its wealth and social prominence rather than its noble status, however. The door was opened to the integration of the new nobility and the moneyed bourgeoisie into the aristocracy, with

Article 80 of the Constitution of the United Kingdom of the Netherlands of 1815.

This new political prominence was derived from the aim of shoring up the new regime. Janssens,

'De restauratie van de adelstand', 392.

64 Aerts, 'Hoe nationaal was het Verenigd Koninkrijk?', 77; Sébastien Dubois, L'invention de la Belgique. Genèse d'un état-nation, 1648-1830

(Brussels 2005); Jan Roegiers, 'Nederlandse vrijheden en trouw aan het Huis van Oostenrijk', in: Roland Mortier and Hervé Hasquin (eds.), Unité et diversité de l'empire des Habsbourg à la fin du XVIIIe siècle (Brussels 1988) 152; Jean Stengers, Histoire du sentiment national en Belgique des origines à 1918 (Brussels 2000-2002); Tom Verschaffel, 'Een lange geschiedenis van scheiding. De Noordelijke en de Zuidelijke Nederlanden vóór het Verenigd Koninkrijk', in: Aerts and Deneckere, Het (on)verenigd Koninkrijk, 43. 
over the common interest, as the failed experiment of the United Belgian Provinces of 1790 illustrates.

Neither did the abolition of the old provinces under French rule signal the end of provincial identification. ${ }^{65}$ After the fall of Napoleon, many Belgians expected a restoration of the old provinces. Members of the old elites petitioned the allied commanders to convene the States-Provincial. ${ }^{66}$ Raepsaet, against his better judgment, defended this course of action even in the Constitutional Commission of 1815 . He maintained that the consent of the old States was a legal necessity for the legitimate introduction of the new constitution in the South. Since the States' abolition by the French, two decades earlier, was not legally valid, the States continued to rightfully represent the Nation. ${ }^{67}$ Despite being laughed away by the other Commission members, the argument shows that provincial sentiments had not at all disappeared.

Neither had they when, fifteen years later, the Belgian Revolution erupted. The 1830 revolution saw a flurry of proposals for the abolition of the unitary state and a return to a federative form of state founded on the rights and privileges of the provinces of the Old Regime. ${ }^{68}$ Inhabitants of abolished provinces, especially from the former Tournaisis, fiercely pleaded for a restoration of former independence. ${ }^{69}$ The Belgian founding fathers nevertheless continued building on the centralist foundations laid by the Napoleonic and Dutch regimes. ${ }^{70}$ Despite remaining important levels of Centralization. French Identity Politics in Brabant', in: Raingard Esser and Steve Ellis (eds.), Region, Memory and Agency in Eastern and Western Europe (Hannover 2013) 217-246; Luc Schepens, 'Historisch overzicht', in: Negen provincies, één land, 8.

\section{Gouverneur-Général de la Belgique (Brussels} 1814). See: Luc François, 'Politieke integratie of exclusie? Belgische notabelen tussen 1785 en 1835', Belgisch Tijdschrift voor Nieuwste Geschiedenis 1-2 (1977) 166; Frank Judo, 'Een huisgemaakte hereniging? De "passiviteit" van de Zuid-Nederlandse elites in een context geplaatst', in: Idem and Van de Perre (eds.), Belg en Bataaf, 52-77; Stefaan Marteel, Inventing the Belgian Revolution. Politics and Political Thought in the United Kingdom of the Netherlands (18141830) (Unpublished doctoral thesis, European University Institute Florence 2009); Witte, 'De Grondwet', 20.
67 Colenbrander II, 306, 'Vergadering van maandag 5 juni $1815^{\prime}$.

68 E.g. Michel Magits, De Volksraad en de opstelling van de Belgische grondwet (Unpublished doctoral thesis, Vrije Universiteit Brussel 1977); Witte, 'De Belgische provinciewet van 1836'; Judo, 'De kracht', 178; Els Witte, 'Het natiebegrip in het Zuidelijk krantendiscours aan de vooravond van de Belgische opstand (augustus 1829 - juni 1830)', Bijdragen en Mededelingen betreffende de Geschiedenis van Nederland - Low Coutries Historical Review 121:2 (2006) 222-236.

69 Magits, De Volksraad, I, 357. Robert Demoulin, 'L'importance d'une loi provinciale dans un jeune état. La loi provincial belge du 30 Avril 1836', in: Actes du 111e Congrès national des sociétés savantes. Les pouvoirs régionaux: représentants et élus (Poitiers 1986) 339-358; Henri Haag, Les droits de la cité. Les catholiques-démocrates et la défense de nos franchises communales, 1833-1836 (Brussels 1946); Witte, 'De Belgische provinciewet', 35-39. 
administration (labelled, together with the municipal level, 'the fourth power' in the Belgian Constitution), the provinces were clearly subordinated to the central government.

After 1830, the provinces functioned as important carriers of the nation-building project. Provincial identities and singularities were celebrated within a Belgian framework, to the effect of strengthening the nation. The same process was at work in other nineteenth-century nation states, with the 'France des régions' as prime example. ${ }^{71}$ At that point, it no longer mattered that the provincial territories mirrored the preceding French departments. The bond with the pre-revolutionary provinces, however artificial, was restored through the cultivation of a romantic historical culture. A particularly artificial province like Limburg even engendered the development of remarkably strong regional identity. ${ }^{72}$ Whether the same principle was at work under the United Kingdom of the Netherlands, remains yet to be proven. Further research should investigate whether or not the establishment of the Southern provinces effectively created a sense of continuity with the past.

\section{Conclusion}

The paradoxical nature of Europe's Restoration regimes has been remarked upon more than once. The Restoration was an era defined by conservatism, repression and the return to the social hierarchy of the Old Regime. At the same time, it was a period of renewal and innovation: an age of state-building, constitutional change and new political arrangements. The establishment of the provinces under the United Kingdom of the Netherlands shows exactly how difficult the search for a balance between elements from Old Regime tradition and modern, post-revolutionary state administration could be. Regional administration was a challenge for all Restoration regimes, since they were founded on the unitary-state model inherited from their revolutionary and Napoleonic predecessors. Even if the replacement of the confederative Dutch Republic by a centralised, monarchical Kingdom was hardly contested, the memory of the Old Regime provinces did not disappear overnight. Integrating the forces of regional identification into the nation state therefore became a major challenge.

This process operated at several levels. Restoring the provincial names, boundaries and institutional particularities served to facilitate popular

Anne-Marie Thiesse, Ils apprenaient la France. L'exaltation des régions dans le discours patriotique (Paris 1997)
Limburg (1986); Karen Arijs, Vormen van regionaal bewustzijn en nationale identiteit in Belgisch- en Nederlands-Limburg, 1866-1938 (Hilversum 2017). 
identification with the regime by appealing to regional sentiments. But it also enabled the government to involve the traditional elites into the new administration, thus creating substantial personal continuity with the old Regime. These elites had been important carriers of provincial identity and perfectly suited the elitist conception of citizenship of the Restoration state. The restoration of provincial elites and rules did not prevent the central government from simultaneously preserving the unitary-state model, however.

The case was complicated by the integration of the Southern Netherlands into the realm. This time, the suggestion of continuity could not simply be obtained by referring back to the period of the glorious Dutch Republic; it took a time leap of more than two centuries to conjure up a common past. The old provinces were essential building blocks of that shared history. However, the administrative reality of the Southern Netherlands after two decades of French rule did not allow for a straightforward restoration of the old provinces, as had been the case in the North. The effort that was put into the nominal preservation of the old provinces, artificially combined with the departmental organisation of French revolutionary origin, perfectly illustrates the ambiguity of the Restoration appeal to the past. The instrumental use of continuity in the United Kingdom of the Netherlands reached its limits when the historical traditions of North and South proved to be too divergent, as shown by the debate over bicameralism.

Nevertheless, the appropriation of pre-modern regional sentiments by the authorities in post-Napoleonic Europe was an important asset for the development of modern national citizenship. Moreover, concrete political gains were to be obtained from creating personal continuity with Old Regime provincial elites. A regionally differentiated approach was indispensable to lending credibility to this policy. The process took on different forms in the Northern and the Southern parts of the realm, depending on each region's pre-revolutionary history.

Dr. Brecht Deseure (1985) is a historian specialising in the political, cultural and constitutional history of the revolutionary era in the Southern Netherlands and Belgium. His dissertation, obtained at the University of Antwerp, was on the politics of history pursued by the French revolutionary and Napoleonic governments in the Belgian departments. It was published in 2014 as Onhoudbaar verleden. Geschiedenis als politiek instrument tijdens de Franse periode in België. Recent publications include 'The Faces of Power. History and the Legitimation of Napoleonic Rule in Belgium', French Historical Studies 40:4 (2017) 555-585 and a special issue of the Journal for Constitutional History/ Giornale di Storia Costituzionale 35:1 (2018) on the history of the Belgian Constitution, which he co-edited with Christophe Maes. He is currently employed as a postdoctoral researcher at the Institute of Philosophy of the KU Leuven, where he investigates the intellectual origins of the Belgian Constitution of 1831. Email: brecht.deseure@kuleuven.be. 
Dr. Diederik Smit (1983) is a postdoctoral researcher in Dutch history at Leiden University. He studied at the University of Groningen and obtained his $\mathrm{PhD}$ at Leiden University in July 2015 with a thesis on the relationship between architecture and politics in the Netherlands in the $19^{\text {th }}$ and $20^{\text {th }}$ century (Het belang van het Binnenhof. Twee eeuwen Haagse politiek, huisvesting en herinnering, Amsterdam 2015). He co-edited a study on the institutional culture of the lower house of the Dutch parliament (In dit Huis. Twee eeuwen Tweede Kamer, Amsterdam 2015) and recently published an article on the architecture of Dutch city halls ('De lokalen van lokaal bestuur. Nederlandse raadhuizen en raadzalen in historisch perspectief', in: Hans Vollaard et al. (eds.), De Gemeenteraad, Amsterdam 2018). His current research project focuses on the persistence of provincial identities in the Netherlands between 1750 and 1850 . This project is part of the Nwo Free Competition Programme 'The Persistence of Civic Identities in the Netherlands, 17471848'. Email: D.E.J.Smit@hum.leidenuniv.nl. 